\title{
Feeding Sources and Natural Infection of Belminus herreri (Hemiptera, Reduviidae, Triatominae) from Dwellings in Cesar, Colombia
}

\author{
Claudia Magaly Sandoval, Rosemere Duarte*, Reinaldo Gutíerrez, \\ Dayse da Silva Rocha**, Victor Manuel Angulo, Lida Esteban, Marlen Reyes, \\ José Jurberg**, Cleber Galvão**/+
}

\begin{abstract}
Centro de Investigaciones en Enfermedades Tropicales, Universidad Industrial de Santander, Santander, Colombia
*Departamento de Ciências Biológicas, Escola Nacional de Saúde Pública-Fiocruz, Rio de Janeiro, RJ, Brasil **Laboratório Nacional e Internacional de Referência em Taxonomia de Triatomíneos, Departamento de Entomologia, Instituto Oswaldo CruzFiocruz, Av. Brasil 4365, 21045-900, Rio de Janeiro, RJ, Brasil
\end{abstract}

Belminus herreri, originally described from specimens collected in Panama, was considered entirely silvatic until to 2000 when it was found for the first time in a domestic habitat in Colombia. In 2001, during a new search of houses in the Department of Cesar, Colombia, 121 specimens were collected. Study of their feeding sources using an ELISA test revealed that $96 \%$ of these specimens had fed on cockroaches (Blattidae). However, a small proportion of these B. herreri specimens also showed the presence of Trypanosoma cruzi in their gut contents, suggesting a possible role for these insects in the epidemiology of Chagas disease.

Key words: Chagas disease - Belminus herreri - Trypanosoma cruzi - Colombia

The subfamily Triatominae (Hemiptera, Reduviidae) currently includes 137 recognised species grouped into six tribes and 19 genera (Galvão et al. 2003). The majority are found in the New World, where several are important vectors of Trypanosoma cruzi - causative agent of Chagas disease. About $80 \%$ of the American species have been reported naturally or experimentally infected with Trypanosoma cruzi (Sherlock et al. 1998).

Among the least well-known groups of Triatominae, the genus Belminus is composed by the species: $B$. rugulosus Stål, 1859, B. costaricensis Herrer, Lent \& Wygodzinsky, 1954, B. peruvianus Herrer, Lent \& Wygodzinsky, 1954, B. herreri Lent \& Wygodzinsky, 1979, B. pittieri Osuna \& Ayala, 1993 and B. laportei Lent, Jurberg \& Carcavallo, 1995. The geographical distribution of these species is discontinuous and known only from small numbers of specimens captured in Central America, Colombia, Peru, Venezuela, and the North of Brazil. The Belminus species found in Colombia are B. rugulosus in the departments of Antioquia and Meta (Molina et al. 2000), and $B$. herreri in Santander and Cesar (Sandoval et al. 2000, Angulo \& Sandoval 2001). B. herreri was considered to be entirely silvatic, until 2000 when it was captured for the first time inside houses in Colombia, during implementation of the "Programa Nacional de Control de La En-

Financial support: Secretaria de Salud del Cesar, Universidad Industrial de Santander, Cintrop, Colombia; agreement Funasa/ Fiocruz/Fiotec, CNPq, and Faperj, Brazil

${ }^{+}$Corresponding author. Fax: 55-21-25607317. E-mail: galvao@ioc.fiocruz.br

Received 18 August 2003

Accepted 5 February 2004 fermedad de Chagas y la Cardiopatia Infantil" in the Department of Cesar. This finding motivated the present work to analyse their feeding sources and natural infection by $T$. cruzi, biological aspects unknown for this species.

\section{MATERIALS AND METHODS}

Study area - The study area is located in the municipality of San Martín, Department of Cesar, Colombia; in the localities of Vega del Oso $\left(07^{\circ} 58^{\prime} \mathrm{N}, 7^{\circ} 22^{\prime} \mathrm{W}\right)$ and Alto de La Paz $\left(8^{\circ} 01^{\prime} \mathrm{N}, 73^{\circ} 24^{\prime} \mathrm{W}\right)$. The dwellings of this area are mainly built of 'wattle and daub' with roofs of thatch or corrugated metal, and their inhabitants are mainly involved in agricultural activities for coffee, cocoa, corn, and banana production. This region is characterized as a tropical humid forest, with an altitude between 500 and 800 m.a.s.l. and average annual temperature of $30^{\circ} \mathrm{C}$ (Figs 1,2).

Capture of Triatominae - In the localities of Vega del Oso and Alto de La Paz, 15 and 16 houses were examined, respectively, during the period of 2-12 July 2001. Examination was by 'man-hour' aided by dislodgant sprays of dilute lambda-cyhalothrin (Icon PM $\left.{ }^{\circledR}\right)$. Captured insects were identified according to the keys of Lent and Wygodzinsky (1979) and Carcavallo et al. (1998a). The insects were then dissected, with the intestinal content of each insect prepared for analysis of bloodmeal source and possible infection with $T$. cruzi. Part of each intestinal content was mixed in $50 \mu$ of PBS (phosphate-buffersaline, $\mathrm{pH}$ 7.2) for ELISA testing of bloodmeal sources; the remainder was deposited in $50 \mu \mathrm{l}$ of Buffer T.E ( $\mathrm{pH}$ 8.1, $10 \mathrm{mM}$ Tris - HCl, 1 mM EDTA) followed by direct microscopy and then storage at $-20^{\circ} \mathrm{C}$ for polymerase chain reaction (PCR) examination.

Bloodmeal analysis - An ELISA test for bloodmeal sources was carried out following the method of Burkot 


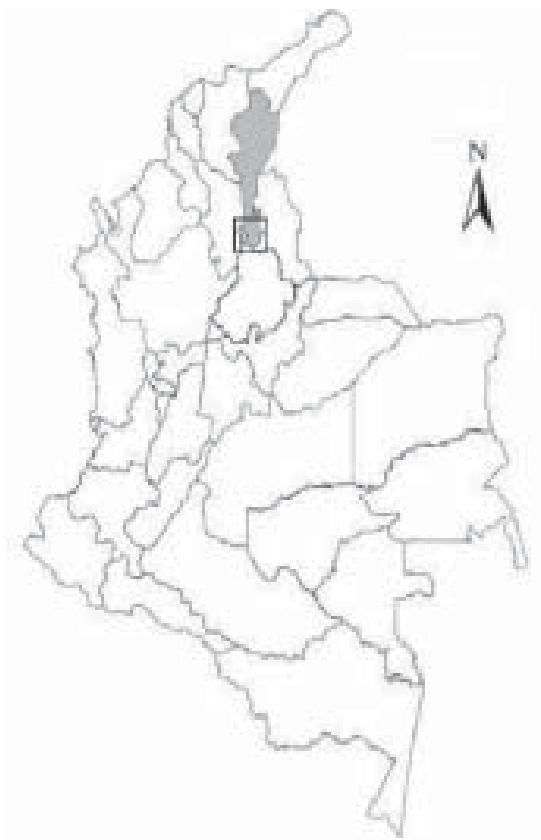

Fig. 1: department of Cesar, Colombia $\square$

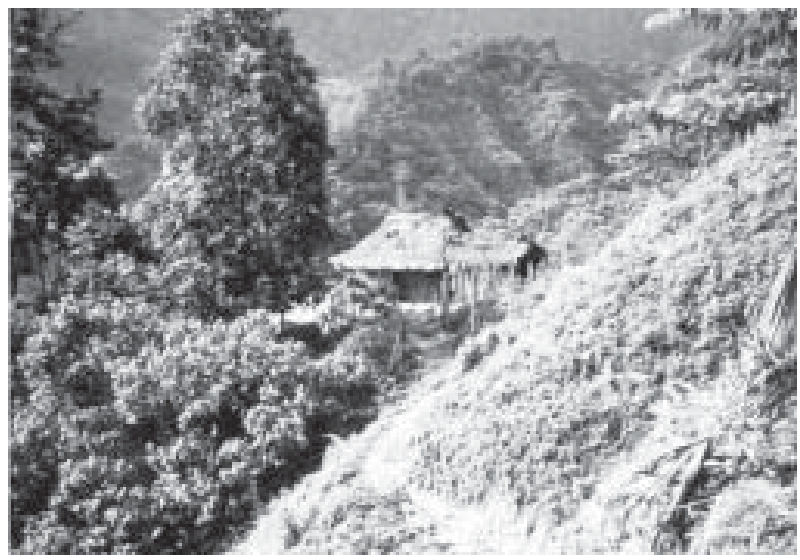

Fig. 2: panoramic view, municipality of San Martin, Cesar, Colombia

et al. (1981) as modified by Duarte (1997) using the following antisera: chicken (Gallus gallus), Blattidae (Periplaneta americana), cat (Felis domestica), dog (Canis familiaris), goat (Capra aegagrus), horse (Eqqus caballus), opossum (Didelphis marsupialis), reptile (Tupinambis merianae), rodent (Rattus norvegicus), and human. Three laboratory-reared specimens of $B$. herreri, fed on laboratory-reared Rhodnius prolixus, were used as control.

$P C R$ for detection of $T$. cruzi - To check for natural infection with $T$. cruzi we used a PCR protocol that specifically amplifies a sequence of $330 \mathrm{bp}$ located in the variable area of kinetoplast DNA, using the primers developed by Sturm et al. (1989). As positive controls we used a sample of faeces of $R$. prolixus shown to be positive by direct microscopy and previously confirmed by the same PCR protocol, and a sample of cultured T. cruzi. As negative controls we used intestinal contents of three different laboratory-reared specimens of $B$. herreri fed on
R. prolixus (Sandoval et al. 2000). PCR reactions were performed according to a "hot start" processes (taq platinum Gibco®). The amplification reaction was carried out as described by Winker et al. (1994) using two primers specific for $T$. cruzi minicircles (No. 121: 5' AAATAATGTACGGG(T/G)GAGATGCATGA-3' and No. 122: 5'-GGTTCGATTGGGGTTGGTGTAATATA-3'). Subsequent to denaturing of DNA at $98^{\circ} \mathrm{C}(2 \mathrm{~min})$, amplification was carried out with thermal cycle of 94 ( $1 \mathrm{~min}), 64$ (1min) 33 times. To visualize the amplified products $15 \mu \mathrm{l}$ of each reaction mixture were loaded in $2 \%$ agarose gel and examined under ultraviolet light after ethidium bromide staining. As a molecular weight marker, we used 100 bp ladder of Invitrogen $®$. All the positive samples and a sample of negatives were also re-extracted by phenol-chloroform and re-amplified for corroboration of the results.

\section{RESULTS}

Domiciliary infestation - From the 31 examined houses, four were found infested with $B$. herreri, representing house infestation rates of $13.3 \%$ in Vega del Oso, and $12.5 \%$ in Alto de La Paz. No other species of Triatominae was encountered in the houses, but large numbers of sylvatic cockroaches were seen. A total of 121 specimens of $B$. herreri was collected from these houses. The dwelling with highest infestation was at Vega del Oso, where 108 specimens were captured, represented by 28 females, 50 males, 25 5th-instar nymphs, and 5 4th-instar nymphs.

Feeding sources - Of the 121 B.herreri specimens captured from houses, 76 were analyzed by ELISA ( 25 males, 31 females and 20 5th-instar nymphs). The other insects were too dry for adequate dissection. From the ten antisera used (bird, Blattidae, cat, dog, goat, horse, opossum, reptile, rodent, and human) all the positive reactions (96.2\%) were positive for Blattidae.

Natural infection with T.cruzi - Of the 76 specimens examined for detection of the feeding sources, 44 had adequate intestinal material for examination of natural infection. None was positive for flagellates by direct microscopy, but four specimens $(9 \%)$ were positive for $T$. cruzi by PCR (two females, one male, and a 5th instar nymph, all having been collected in the same house) (Fig. 3).

\section{DISCUSSION}

The biology of the six species of Belminus is poorly known, with information about feeding sources limited to Herrer et al. (1954), who collected B. peruvianus from human dwellings in the Valle del Marañon in Perú. These authors reported that in the laboratory, 1st instar nymphs did not feed on chickens, rabbits, guinea pigs, mice, or humans, but would feed on lizards, turtles, and other species of Triatominae recently fed on mammals or birds, while more advanced instars fed well on chickens, lizards, and humans.

The results obtained in the present work suggest that in a natural environment, $B$. herreri also uses arthropods as feeding source. The $96.2 \%$ of positivity to Blattidae antiserum is reflected by the high numbers of cockroaches found in the examined houses, and by feeding of $B$. herreri 


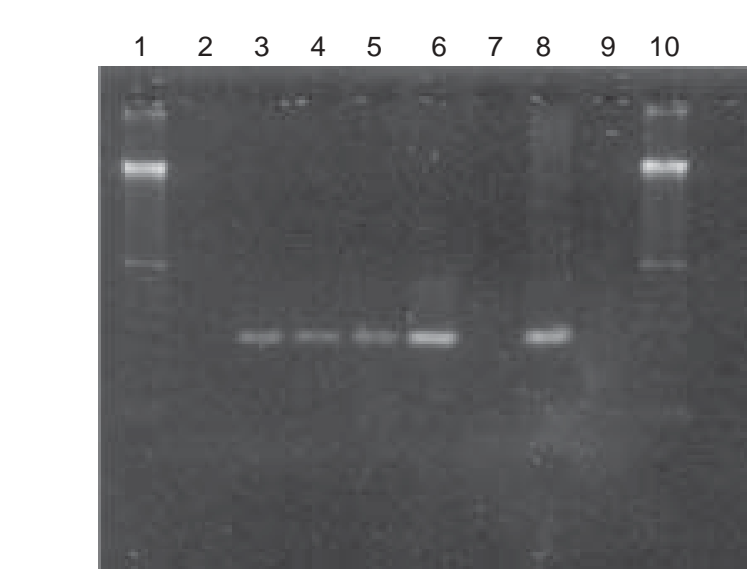

Fig 3: polymerase chain reaction results, agarose gel showing the amplified products. 1 and 10: molecular weight marker; 2 and 7 : negative intestinal content; $3,4,5,6$ : positive intestinal content; 8: positive control (Trypanosoma cruzi parasites); 9: reaction control

on cockroaches in the laboratory. Such 'ectoparasitic' haemolymphagy has also been shown for several other species of Triatominae. The first reports of this were made by Brumpt (1914) and Ryckman (1951), followed by a report of Eratyrus mucronatus feeding on spiders (Miles et al. 1981). More recently, laboratory studies with T. circummaculata, T. rubrovaria, and T. carcavalloi, suggest that such behaviour is common in these species (Lorosa et al. 2000, Ruas-Neto et al. 2001). This could be interpreted simply as a reflection of host availability in their habitats or, according to Schofield (2000), it may also suggest a recent adaptation to a blood-feeding strategy.

The life cycle of $B$. herreri in laboratory conditions was observed by Sandoval et al. (2000) starting from specimens caught in the municipality of El Carmen, department of Santander, Colombia, feeding them on specimens of laboratory-reared $R$. prolixus that had been fed on chicken blood. These studies suggested that although $B$. herreri may be primarily of predatory haemolymphagous habit, it can also take vertebrate blood from the intestine of another blood-sucking insect. Such behaviour might also explain our finding of a small proportion of $B$. herreri positive for $T$. cruzi by PCR, except that we did not encounter any specimens of $R$. prolixus or other haematophagous insects in the houses examined. We therefore assume that the $B$. herreri specimens, although apparently feeding primarily from cockroaches, are also able to take blood directly from infected vertebrates.

From previous reports, species of the genus Belminus are generally considered to be arboreal in habit, having been found mainly among bromeliads or under tree bark, associated with sloths, opossums, lizards, and insect nests (Lent \& Wygodzinsky 1979, Carcavallo et al. 1998b). However, the finding of specimens of $B$. herreri colonizing human houses, added to the report of $B$. peruvianus in similar conditions (Herrer et al. 1954) [and a recent finding of what appears to be another species of Belminus in houses elsewhere in Colombia (Sandoval et al., unpublished)] suggests that species of this genus are able to adapt to domestic habitats. They perhaps enter the domi- cile by active or passive dispersal, and encounter abundant invertebrate hosts in the form of cockroaches that would facilitate their population development. Alternatively, they may be attracted by the presence of cockroaches or other arthropods inside the houses, as also suggested by De la Riva et al. (2001) to explain the presence of Microtriatoma trinidadensis in peridomestic structures infested also with $R$. stali. However, although Esteban et al. (2002) showed that adults and nymphs of $B$. herreri possesed the same morphological types of sensilla described for other Triatominae (bristles, thin and thick trichoidea, and basiconica) these authors also reported that these sensilla were remarkably reduced in number, and with only one chemoreceptor type (thinwalled trichoids) on the adult pedicel. Following Catalá (1997), who showed that triatomine species with high densities of pedicel chemosensilla tended also to have extensive habitat ranges, it is surprising that B.herreri - with relatively few chemosensilla - appears able to colonise a wide range of habitats.

Our results, allied to other observations, indicate that $B$. herreri can exploit a wide range of hosts including arthropods, reptiles, and mammals, and is able to occupy a range of habitats. And although we cannot definitively incriminate this species as a vector of $T$. cruzi, our finding of PCR-positive specimens suggests that this species may have some vector potential.

\section{ACKNOWLEDGMENTS}

To the staff of the Laboratório de Biologia Molecular e Doenças Endêmicas, Departamento de Bioquímica e Biologia Molecular, Oswaldo Cruz Institute, for providing technical assistance for the PCR analysis. To Dr CJ Schofield for critical reading and English review of this paper.

\section{REFERENCES}

Angulo VM, Sandoval CM 2001. Triatominos y Programa Nacional de Control en Colombia. Serie Enfermedades Transmisibles. Monitoreo de la resistencia a insecticidas en triatominos en América Latina. Fundación Mundo Sano 1: 21-26.

Brumpt E 1914. Importance du cannibalisme et de la coprofhagie chez les Réduvidés hématophages (Rhodnius, Triatoma) pour la conservation des trypanosomes pathogénes en dehors de l'hote vertébré. Bull Soc Pathol Exot 7: 702-705.

Burkot, TR, Goodman WG, De Foliartt GR 1981. Identification of mosquito blood meals by enzyme-linked immunosorbent assay. Am J Trop Med Hyg 30: 1336-1341.

Carcavallo RU, Galíndez-Girón I, Jurberg J, Galvão C, Lent H 1998a. Pictorial keys for tribes genera and species of the subfamily Triatominae. In RU Carcavallo, I Galíndez-Girón, J Jurberg, H Lent (eds), Atlas of Chagas Disease Vectors in the Americas, Vol. 1, Fiocruz, Rio de Janeiro, p. 127-131.

Carcavallo RU, Franca Rodriguez ME, Salvatella R, Curto de Casas SI, Sherlock I, Galvão C, Silva Rocha D, GalíndezGirón I, Otero Arocha MA, Martinez A, Aristeu da Ross J, Canale DM, Farr TH, Barata JM 1998b. Habitats and related fauna. In RU Carcavallo, I Galíndez-Girón, J Jurberg, H Lent (eds), Atlas of Chagas Disease Vectors in the Americas, Vol. 2, Fiocruz, Rio de Janeiro, p. 561-600.

Catalá S 1997. Antennal sensilla of Triatominae (Hemiptera: Reduviidae): a comparative study of five genera. Int J Insect Morphol \& Embryol 2: 63-67.

De la Riva J, Matias A, Torrez M, Martínez E, Dujardin JP 
2001. Adult and nymphs of Microtriatoma trinidadensis (Lent, 1951) (Hemiptera: Reduviidae) caught from peridomestic environment in Bolivia. Mem Inst Oswaldo Cruz, 96: 889-894.

Duarte R 1997. Ensaio Imunoenzimático ELISA para Identificação Experimental de Fontes Alimentares em Panstrongylus megistus (Burmeister, 1835) (Hemiptera: Reduviidae), MSc Thesis, IOC-Fiocruz, $103 \mathrm{pp}$.

Esteban L, Sandoval CM, Angulo VM, Catalá S 2002. Estúdio morfológico de los patrones sensoriales em adultos y ninfas de Belminus herreri (Reduviidae: Triatominae). II Congreso del Instituto Nacional de Salud 22 (Supl. 1): 113.

Galvão C, Carcavallo RU, Rocha DS, Jurberg J 2003. A checklist of the current valid species of the subfamily Triatominae Jeannel, 1919 (Hemiptera, Reduviidae) and their geographical distribution, with nomenclatural and taxonomic notes. Zootaxa 202: 1-36.

Herrer A, Lent H, Wygodzinsky P 1954. Contribución al conocimiento del género Belminus Stal, 1859 (Triatominae, Reduviidae, Hemiptera). An Inst Med Reg Univ Tucuman 4: 85106.

Lent H, Wygodzinsky P 1979. Revision of the Triatominae (Hemiptera, Reduviidae) and their significance as vector of Chagas disease. Bull Am Mus Nat Hist 163: 127-520.

Lorosa ES, Jurberg J, Souza AL, Vinhaes MC, Nunes IM 2000. Hemolinfa de Dictyoptera na manutenção do ciclo biológico silvestre de Triatoma rubrovaria (Blanchard, 1843) e Triatoma circummaculata (Stal, 1859) (Hemiptera, Reduviidae, Triatominae). Entomol Vect 7: 287-296.

Miles A, Arias JR, de Souza A, Póvoa M 1981. Chagas disease in the Amazon basin III. Ecotopes of ten triatomine bug species (Hemiptera: Reduviidae) from the vicinity of Belém,
Para state, Brazil. J Med Entomol 18: 266-278.

Molina JA, Gualdron LE, Bochero HL, Olano V, Barrios D, Gulh F 2000. Revisión de la distribución actual e importancia epidemiológica de las especies de triatominos (Reduviidae: Triatominae) en Colombia. Biomédica 20: 344-360.

Ruas-Neto AL, Corseuil E, Cavalleri A 2001. Development of rupestrian triatomines (Hemiptera: Reduviidae: Triatominae) following hemolymphagy on blaberids (Blattodea: Blaberidae) in Rio Grande do Sul State, Brazil. Entomol Vect 8: 205-216.

Ryckman RE 1951. Recent observations of cannibalism in Triatoma (Hemiptera:Reduviidae). J Parasitol 37:433-434.

Sandoval CM, Joya M, Gutiérrez M, Angulo VM 2000. Cleptohaemathophagia in B. herreri. Med Vet Entomol 14: 100101.

Schofield CJ 2000. Biosystematics and evolution of the Triatominae. Cad Saúde Pública 16: 89-92.

Sherlock I, Carcavallo RU, Galíndez-Girón I 1998. List of natural and experimental flagellate infections in several Triatominae species. In RU Carcavallo, I Galíndez-Girón, J Jurberg, H Lent (eds). Atlas of Chagas DiseaseVectors in the Americas, Vol. 1, Fiocruz, Rio de Janeiro, 289-298.

Sturm NR, Degrave W, Morel C, Simpson 1989. Sensitive detection and schizodeme classification of Trypanosoma cruzi, cells by amplification of kinetoplast minicircle DNA sequences use in diagnosis of Chagas disease. Mol Biochem Parasitol 33: 205-214.

Wincker P, Britto C, Borges-Pereira J, Cardoso MA, Oelemann W, Morel CM 1994. Use of a simplified polymerase chain reaction procedure to detect Trypanosoma cruzi in flood samples from chronic chagasic patients in a rural endemic area. Am J Trop Med Hyg 51: 771-777. 